\section{Review of Copper Provision in the Parenteral Nutrition of Adults}

\author{
Callum Livingstone, FRCPath ${ }^{1,2}$
}

Nutrition in Clinical Practice

Volume XX Number X

Month 201X 1-13

C) 2016 American Society

for Parenteral and Enteral Nutrition DOI: $10.1177 / 0884533616673190$ ncp.sagepub.com

hosted at

online.sagepub.com

@SAGE

\begin{abstract}
The essential trace element copper $(\mathrm{Cu})$ is required for a range of physiologic processes, including wound healing and functioning of the immune system. The correct amount of $\mathrm{Cu}$ must be provided in parenteral nutrition (PN) if deficiency and toxicity are to be avoided. While provision in line with the standard recommendations should suffice for most patients, $\mathrm{Cu}$ requirements may be higher in patients with increased gastrointestinal losses and severe burns and lower in those with cholestasis. The tests of $\mathrm{Cu}$ status that are currently available for clinical use are unreliable. Serum $\mathrm{Cu}$ concentration is the most commonly ordered test but is insensitive to $\mathrm{Cu}$ deficiency and toxicity and is misleadingly increased during the acute phase response. These limitations make it difficult for prescribers to assess $\mathrm{Cu}$ status and to decide how much $\mathrm{Cu}$ to provide. There is a need for better tests of $\mathrm{Cu}$ status to be developed to decrease uncertainty and improve individualization of $\mathrm{Cu}$ dosing. More information is needed on $\mathrm{Cu}$ requirements in disease and $\mathrm{Cu}$ contamination of $\mathrm{PN}$ components and other intravenous fluids. New multi-trace element products should be developed that provide $\mathrm{Cu}$ doses in line with the 2012 American Society for Parenteral and Enteral Nutrition recommendations. This article discusses the evaluation and treatment of $\mathrm{Cu}$ deficiency and toxicity in patients treated with PN. (Nutr Clin Pract. XXXX;xx:xx-xx)
\end{abstract}

\title{
Keywords
}

copper; copper deficiency; copper toxicity; parenteral nutrition; nutritional support

Copper $(\mathrm{Cu})$ is an essential trace element (TE) required for metabolism in all living cells. It has been known to be an essential component of parenteral nutrition (PN) since 1972. ${ }^{1}$ Provision of the correct amount of $\mathrm{Cu}$ is necessary, not only to avoid deficiency and toxicity, but also to promote optimal recovery. ${ }^{2}$ This article covers the relevant physiology of $\mathrm{Cu}$. It then discusses $\mathrm{Cu}$ deficiency and toxicity and examines the evidence behind the recommendations on $\mathrm{Cu}$ provision in PN. It provides practical guidance on assessment of $\mathrm{Cu}$ status and $\mathrm{Cu}$ requirements. The article focuses on adults because provision of $\mathrm{Cu}$ in pediatric $\mathrm{PN}$ has recently been covered elsewhere, ${ }^{3}$ but pediatric studies have been cited where considered appropriate.

\section{Physiology}

$\mathrm{Cu}$ is among the 3 most abundant transition metals in biological systems, the other 2 being iron (Fe) and zinc ( $\mathrm{Zn})$. The human body contains around $100 \mathrm{mg}$ of $\mathrm{Cu}$, more than half of which is in bone and muscle. The highest concentrations are in liver, kidney, and brain, reflecting the high metabolic activity of these organs. ${ }^{2}$ Only $5 \%$ is in blood, about $95 \%$ of this being bound to ceruloplasmin $(\mathrm{Cp})$ and the remainder to albumin and amino acids. ${ }^{4}$ The serum $\mathrm{Cu}$ concentration therefore largely reflects the $\mathrm{Cp}$ concentration and is affected by factors influencing $\mathrm{Cp}$. Intracellular $\mathrm{Cu}$ is usually bound to chaperones and other proteins because free $\mathrm{Cu}$ is potentially harmful to cells.

$\mathrm{Cu}$, which functions as a component of cuproproteins, has a variety of physiologic roles. For example, it is required for humoral immunity and production of inflammatory cytokines. ${ }^{5,6}$ It was recently suggested that the immune system uses $\mathrm{Cu}$ intoxication as a means of intracellular bacterial killing. ${ }^{7,8} \mathrm{Cu}$ is required for the physiologic response to low $\mathrm{Fe}$ stores. It is needed for absorption of dietary Fe, release of Fe from hepatocytes and production of hemoglobin. ${ }^{9} \mathrm{Cp}$ oxidizes Fe from the ferrous to ferric state, enabling its transport by transferrin and subsequent use in erythropoiesis. Superoxide dismutase is an antioxidant cuproenzyme that catalyzes the conversion of superoxide radicals to hydrogen peroxide, which is then reduced to water. ${ }^{10} \mathrm{Cu}$ is also necessary for wound healing because it is required for the synthesis of collagen.

The average daily oral intake of $\mathrm{Cu}$ is $1.0-1.6 \mathrm{mg}$, which exceeds the RDA of 0.9 mg. ${ }^{11}$ Dietary $\mathrm{Cu}$ is absorbed mainly in the stomach and upper small intestine. ${ }^{2,12}$ About 55\%-75\% of dietary $\mathrm{Cu}$ is absorbed, which is a high proportion as compared

From the ${ }^{1}$ Clinical Biochemistry Department, Royal Surrey County Hospital NHS Foundation Trust, Guildford, UK; and the ${ }^{2}$ Faculty of Health and Medical Sciences, University of Surrey, Guildford, Surrey, UK.

Financial disclosure: None declared.

Conflicts of interest: None declared.

Corresponding Author:

Callum Livingstone, FRCPath, Clinical Biochemistry Department, Royal Surrey County Hospital NHS Foundation Trust, Guildford, Surrey, GU2 7XX, UK.

Email: callum.livingstone@nhs.net 
with other TEs. ${ }^{2}$ The amount of $\mathrm{Cu}$ absorbed depends on dietary intake, $\mathrm{Cu}$ status, and the effects of other nutrients. Absorption is decreased by vitamin $\mathrm{C}, \mathrm{Fe}$, and $\mathrm{Zn}{ }^{2} \mathrm{Zn}$ inhibits $\mathrm{Cu}$ transport directly and by inducing metallothioneins that bind $\mathrm{Cu}$ in intestinal mucosal cells. Short-chain fructo-oligosaccharides $^{13}$ and Fe deficiency ${ }^{9}$ increase $\mathrm{Cu}$ absorption. Once absorbed, $\mathrm{Cu}$ is bound to albumin and transcuprein and transported to the liver, where it is stored, released into the systemic circulation, or excreted into bile. Normally, about $80 \%$ of $\mathrm{Cu}$ excreted from the body is in bile and gastrointestinal (GI) secretions, and about $20 \%$ is in urine. ${ }^{14,15}$ About $10 \%-15 \%$ of biliary $\mathrm{Cu}$ is reabsorbed, returning to the liver in an enterohepatic circulation. External fluid losses from fistulae, bile leaks, or enterostomies predispose to $\mathrm{Cu}$ deficiency by decreasing the amount of $\mathrm{Cu}$ reabsorbed.

\section{Cu Deficiency}

Deficiency occurs when $\mathrm{Cu}$ intake is consistently below requirements. This section focuses on $\mathrm{Cu}$ deficiency encountered among patients receiving nutrition support. Factors affecting individual susceptibility to deficiency during PN include the size of hepatic $\mathrm{Cu}$ stores, the extent of GI losses, and the amount of $\mathrm{Cu}$ provided. $\mathrm{Cu}$ provision includes supplementation of PN but also the amount delivered by concurrent oral or enteral nutrition and as a contaminant of PN and other intravenous (IV) fluids.

\section{Causes of $C u$ Deficiency}

Overt $\mathrm{Cu}$ deficiency is uncommon during short-term PN but has occurred during long-term $\mathrm{PN}$ when $\mathrm{Cu}$ has been provided below requirements. ${ }^{16-19}$ A recent retrospective review of the $\mathrm{Cu}$ status of hospitalized pediatric patients treated with $\mathrm{PN}$ observed that, after 14 days of treatment, hypocupremia was present in $71 \%$ of patients receiving $\mathrm{PN}$ unsupplemented with $\mathrm{Cu}$, as compared with $50 \%$ of those receiving supplemented PN. ${ }^{20}$ Deficiency has also occurred when supplemental $\mathrm{Cu}$ has been withheld either because of concern about accumulation during cholestasis ${ }^{21,22}$ or because of shortages of multi-TE (MTE) products. ${ }^{23-25}$ There is much concern about the clinical implications of such shortages, especially for infants, for whom micronutrient deficiency can have irreversible consequences. ${ }^{26}$ The prevalence of marginal $\mathrm{Cu}$ deficiency among patients treated with PN is unknown but could be anticipated to be higher than that in the general population, given the higher prevalence of risk factors for deficiency in hospitalized patients.

Short bowel syndrome. Patients with short bowel syndrome (SBS) are at risk of $\mathrm{Cu}$ deficiency even after weaning onto oral diet. A recent study investigated 22 adults with SBS following intestinal resection, of whom half had been weaned onto oral diet and half remained dependent on $\mathrm{PN} .{ }^{27}$ Patients in the PN group had a small intestine with a median length of $25 \mathrm{~cm}$ (range, 10-100), and 6 patients had a colon. Patients in the orally fed group had a small intestine with a median length of $110 \mathrm{~cm}$ (range, 40-210), and 9 patients had a colon. Serum $\mathrm{Cu}$ concentrations were significantly lower for the patients treated with $\mathrm{PN}(69 \pm 24 \mu \mathrm{g} / \mathrm{L}, P<.05)$ and patients taking oral diet (72 $\pm 26 \mu \mathrm{g} / \mathrm{L}, P<.05)$, as compared with a control group (109 $\pm 16 \mu \mathrm{g} / \mathrm{L}$; reference range, $70-140 \mu \mathrm{g} / \mathrm{L})$. Similarly, Cu deficiency can occur during transition from PN to enteral nutrition (EN). A study of transition to EN for pediatric patients reported $\mathrm{Cu}$ deficiency as the most common among micronutrients, affecting $56 \%$ of patients. ${ }^{28}$ After full EN was established, deficiency of $\mathrm{Cu}$ was less prevalent $(22 \%)$ than vitamin D $(68 \%)$, $\mathrm{Zn}(67 \%)$, or $\mathrm{Fe}(32 \%)$. These findings emphasize the importance of monitoring $\mathrm{Cu}$ status among patients with SBS, irrespective of the type of nutrition support.

Teduglutide - an analogue of glucagon-like peptide 2, which is an intestinal growth factor-has been used in patients with SBS to improve absorption of dietary nutrients and decrease dependence on PN. A recent case series reported on adverse events during weaning of patients treated with teduglutide. ${ }^{29}$ One patient developed overt $\mathrm{Cu}$ deficiency, despite $\mathrm{Cu}$ supplementation, which did not respond to oral supplementation and necessitated recommencement of PN. In this patient, it appears that $\mathrm{Cu}$ absorption did not improve in response to teduglutide. Glucagon-like peptide 2 has recently been observed to improve bile flow in an animal model of cholestasis, ${ }^{30}$ but its effect on $\mathrm{Cu}$ balance in humans is unknown.

Enteral tube feeding. Patients receiving long-term EN, especially those fed through a jejunostomy tube, are at risk of developing $\mathrm{Cu}$ deficiency. For example, one case series compared 23 patients fed through percutaneous endoscopic jejunostomy and 36 patients fed via percutaneous endoscopic gastrostomy. ${ }^{31}$ After 6 months of $\mathrm{EN}$, serum $\mathrm{Cu}$ was significantly lower in the percutaneous endoscopic jejunostomy group $(P<.001)$. Six patients in this group had severe $\mathrm{Cu}$ deficiency with hematologic features. There have also been reports of severe $\mathrm{Cu}$ deficiency in patients on home $\mathrm{EN}$ via percutaneous endoscopic gastrostomy. ${ }^{32}$ Enterally fed patients appear to be at risk of $\mathrm{Cu}$ deficiency because of decreased bioavailability rather than inadequate intake. The risk is higher in jejunostomy-fed patients because the main sites of $\mathrm{Cu}$ absorption are bypassed. In addition, interindividual variation in $\mathrm{Cu}$ absorption is high. Furthermore, absorption may be impaired by high enteral intake of $\mathrm{Zn}$ or Fe.

Bariatric surgery. Cu deficiency can occur after bariatric surgery, more commonly after biliopancreatic diversion than after Roux-en-Y gastric bypass. A 5-year follow-up study observed hypocupremia postoperatively in $30.3 \%$ of patients with biliopancreatic diversion, compared with $3.8 \%$ of patients with Roux-en-Y gastric bypass. ${ }^{33}$ None of the patients had hematologic or neurologic features of deficiency, which suggests that, for overt deficiency to occur, deficiency must be sustained 
long-term. $\mathrm{Cu}$ deficiency after bariatric surgery has recently been reviewed. ${ }^{34,35}$ Clinical $\mathrm{Cu}$ deficiency has been described but is unusual for patients receiving adequate supplementation. The American Association of Clinical Endocrinologists' guidelines for perioperative support of the patient undergoing bariatric surgery recommend that $\mathrm{Cu}$ does not need to be routinely measured postoperatively but should be measured if there are hematologic or neurologic features consistent with deficiency or if there is impaired wound healing. ${ }^{36}$ Clinicians should monitor patients carefully for these features.

$\mathrm{Zn}$ excess. $\mathrm{Zn}$-induced $\mathrm{Cu}$ deficiency (ZICD) has been caused by excessive ingestion of $\mathrm{Zn}$, but there is limited awareness among clinicians of this potential side effect of $\mathrm{Zn}$ supplementation. ${ }^{37}$ It tends to occur with oral $\mathrm{Zn}$ doses $>850$ $\mathrm{mg} / \mathrm{d}$ for 1 year, but negative $\mathrm{Cu}$ balance has resulted from doses of $18.5 \mathrm{mg} / \mathrm{d}$ for 2 weeks. ${ }^{38}$ Misdiagnosis of $\mathrm{Zn}$ deficiency during an acute phase response (APR) can result in inappropriate Zn supplementation. ZICD should therefore be considered for patients treated with PN, many of whom have an ongoing APR and high $\mathrm{Zn}$ requirements. For patients treated with PN, the source of excess $\mathrm{Zn}$ may not necessarily be parenteral. For example, excessive intake of $\mathrm{Zn}$ from a denture adhesive was recently reported to cause ZICD for a patient on long-term PN containing standard Cu provision. ${ }^{39}$ The patient presented with mild pancytopenia and perioral paraesthesia, which did not respond to additional $\mathrm{Cu}$ provision but resolved after the adhesive was switched to a $\mathrm{Zn}$ free product. To facilitate diagnosis of ZICD, it has been recommended that, following the finding of hypocupremia, TE laboratories should automatically measure the $\mathrm{Zn}$ of the specimen. ${ }^{40}$ Similarly, the finding of hyperzincemia should prompt the measurement of $\mathrm{Cu}$ to exclude ZICD. To avoid $\mathrm{ZICD}$, it has been suggested that, to treat $\mathrm{Zn}$ deficiency, $1 \mathrm{mg}$ of $\mathrm{Cu}$ should be given for every 8-15 $\mathrm{mg}$ of $\mathrm{Zn}$ (elemental doses). ${ }^{36} \mathrm{Zn}$ and $\mathrm{Cu}$ should be taken at least 2 hours apart to maximize the absorption of $\mathrm{Cu}^{41}$

Other causes of $\mathrm{Cu}$ deficiency. Cutaneous exudative $\mathrm{Cu}$ losses amounting to $37 \mathrm{mg} / \mathrm{wk}$ have been reported for patients with severe burns. ${ }^{42}$ There is evidence that supplementation of $\mathrm{Cu}$ in combination with other micronutrients improves the clinical outcome for patients with burns ${ }^{43}$ or pressure ulcers. ${ }^{44}$ The results of 2 randomized controlled trials were combined in which patients with burns received placebo or a combination of $\mathrm{Cu}$, selenium, and $\mathrm{Zn}$ at doses up to $4 \mathrm{mg}, 500 \mu \mathrm{g}$, and 40 $\mathrm{mg}$, respectively, by IV infusions not associated with PN use. ${ }^{45}$ In total, 41 patients were investigated for up to 21 days. There was a significant reduction in nosocomial pneumonia in patients supplemented with TE. The extent to which this outcome was attributable to $\mathrm{Cu}$ is unknown.

As with other micronutrients, $\mathrm{Cu}$ is readily dialyzed. Continuous renal replacement therapy can result in significant $\mathrm{Cu}$ losses, especially if prolonged. If $\mathrm{Cu}$ provision is insufficient to replace losses, this will lead to negative $\mathrm{Cu}$ balance. Effluent losses of $0.41 \mathrm{mg} / \mathrm{d}$ have been reported, ${ }^{46}$ an amount similar to the recommended $\mathrm{Cu}$ provision in PN. In the same study, $\mathrm{Cu}$ was undetectable in replacement solutions. Hemodialysis and peritoneal dialysis have not been associated with $\mathrm{Cu}$ deficiency in human subjects, but a recent study in an animal model concluded that hemofiltration may necessitate $\mathrm{Cu}$ replacement at doses exceeding standard provision. ${ }^{47}$

Chemotherapy with cisplatin should be considered a risk factor for $\mathrm{Cu}$ deficiency. Patients with esophageal cancer treated with cisplatin and $\mathrm{PN}$ had significantly lower serum $\mathrm{Cu}$ concentrations postchemotherapy $(P=.015) .{ }^{48}$ This change was prevented by additional TE supplementation. Iatrogenic $\mathrm{Cu}$ deficiency has also been observed following overtreatment with chelating agents, such as penicillamine, trientine, and tetrathiomolybdate, but this has not been reported in the context of PN. ${ }^{49}$

\section{Features of Cu Deficiency}

When intake is below requirements, $\mathrm{Cu}$ is initially replenished from hepatic stores. As a result, features of deficiency may occur long after the causal insult. When deficiency has occurred after omission of $\mathrm{Cu}$ from $\mathrm{PN}$, clinical features have taken between 6 weeks and 15 months to appear. ${ }^{21-23,25,50,51}$ In a series of 26 cases of neurologic complications occurring after bariatric surgery, overt $\mathrm{Cu}$ deficiency presented as late as 9 years postoperatively. ${ }^{52}$

The clinical features of $\mathrm{Cu}$ deficiency are mainly hematologic and neurologic, reflecting the requirement for $\mathrm{Cu}$ in erythropoiesis and synthesis of myelin..$^{53}$ The most common features are a microcytic or normocytic anemia, unresponsive to Fe supplementation, and neutropenia. ${ }^{54}$ The mechanism whereby anemia develops is uncertain, but decreased $\mathrm{Cp}$ may result in impaired mobilization of $\mathrm{Fe}$ stores. $\mathrm{Cu}$ deficiency is also implicated in increased oxidative stress and deterioration in cognitive function for patients with Alzheimer's disease. ${ }^{55}$

The most common neurologic feature of $\mathrm{Cu}$ deficiency is myelopathy, but peripheral neuropathy and demyelination have also been reported. ${ }^{56}$ The deficits of myelopathy resemble those of subacute combined degeneration of the cord resulting from vitamin $\mathrm{B}_{12}$ deficiency. ${ }^{57}$ Patients typically present with a disordered gait and sensory ataxia. The mechanism of neurologic damage is unknown, but cuproenzymes such as cytochrome $\mathrm{C}$ oxidase have vital roles in the nervous system, the impairment of which would be expected to have adverse effects. When neurologic features consistent with $\mathrm{Cu}$ deficiency are present, the patient should be investigated by measurement of serum $\mathrm{Cu}$ and by spinal magnetic resonance imaging. In a case series of 25 patients with $\mathrm{Cu}$ deficiency myelopathy, abnormalities on magnetic resonance imaging were found in $44 \%$, the most common being an increased T2 signal of the dorsal column in the cervical and thoracic cord. ${ }^{58}$ In this case series, the duration of patients' symptoms prior to diagnosis of $\mathrm{Cu}$ deficiency ranged 
from 2 months to 10 years. Treatment with $\mathrm{Cu}$ supplementation may arrest the neurologic deficits and result in improvement in sensory symptoms, but most patients have residual deficits resulting from irreversible neurologic injury. This emphasizes the importance of early diagnosis. Several months of $\mathrm{Cu}$ supplementation are likely to be required before the features improve. A study of 12 patients with $\mathrm{Cu}$ deficiency, all of whom had neurologic features, observed significant improvements in functional activities of daily living $(P=.007)$ over 12 months of Cu supplementation. ${ }^{59}$

Nephrotic syndrome was recently reported as a feature of $\mathrm{Cu}$ deficiency for a patient treated with PN following bowel resection. ${ }^{60}$ The patient also had anemia, neutropenia, and deteriorating kidney function, which responded to $\mathrm{Cu}$ supplementation. The urinary protein loss was attributed to loss of the protective effect of $\mathrm{Cp}$ on glomeruli. While this is the only published case report of nephrotic syndrome resulting from $\mathrm{Cu}$ deficiency, urinary protein loss has been reported to correlate with urine $\mathrm{Cu}$ for patients with nephrotic syndrome. ${ }^{61}$

$\mathrm{Cu}$ deficiency should be considered when metabolic bone disease occurs for patients treated with PN. The earliest reported case of $\mathrm{Cu}$ deficiency for a patient treated with PN was an infant who presented with osteoporosis and growth delay. ${ }^{1}$ Osteoporosis resulting from $\mathrm{Cu}$ deficiency was also reported in 2 preterm infants with SBS treated with long-term PN. ${ }^{62}$ It was diagnosed at 5 months of age following investigation for musculoskeletal discomfort. Both patients had severe hypocupremia and responded to IV supplementation of $\mathrm{Cu}$. Pseudoscurvy has been reported as a feature of $\mathrm{Cu}$ deficiency, ${ }^{63}$ as demonstrated in a 4-month-old female infant treated with PN from which TEs had been omitted.

There is evidence from numerous sources that $\mathrm{Cu}$ deficiency impairs the activity of the immune system, thereby predisposing to bacterial infection. ${ }^{5,64}$ In vitro studies have observed decreased neutrophil function, decreased secretion of interleukin 2 from lymphocytes, and decreased cytotoxic activity of natural killer cells. Mortality from infection is higher in $\mathrm{Cu}$-deficient animals. ${ }^{65}$ For humans, it has long been known that $\mathrm{Cu}$ deficiency impairs phagocytosis ${ }^{66}$ and increases mortality from infection. ${ }^{67}$ Pulmonary and urinary tract infections are more common for patients with Menkes's disease, an inherited disorder of severe $\mathrm{Cu}$ deficiency. ${ }^{68}$ The results of supplementation studies for patients with burns, discussed above, also suggest that $\mathrm{Cu}$ deficiency predisposes to pneumonia. ${ }^{45}$ The conclusions that can be drawn from clinical studies regarding the role of $\mathrm{Cu}$ deficiency in infection are limited, given that micronutrient deficiencies do not occur in isolation; but, when taken together, the evidence is compelling to suggest that $\mathrm{Cu}$ deficiency impairs the immune system.

The clinical consequences of marginal $\mathrm{Cu}$ deficiency are unknown but may include neurologic,${ }^{57}$ cardiac, ${ }^{69}$ and immune dysfunction. ${ }^{5,70} \mathrm{~A}$ low- $\mathrm{Cu}$ diet has resulted in decreased proliferation of mononuclear cells. ${ }^{71}$ Given the extensive role of $\mathrm{Cu}$ in $\mathrm{Fe}$ metabolism, it could be anticipated that marginal $\mathrm{Cu}$ deficiency may compromise utilization of Fe. These observations suggest that marginal $\mathrm{Cu}$ deficiency could be detrimental for patients treated with PN, but this awaits investigation.

\section{Treatment of $\mathrm{Cu}$ Deficiency}

The underlying cause of deficiency should be sought and treated. For patients already supplemented with $\mathrm{Cu}$, the dose should be reviewed and possible factors decreasing bioavailability considered. Ideally, supplementation should be delivered orally or enterally, to enable absorption according to requirements and to avoid bypassing homeostatic mechanisms. However, for patients treated with PN, enteral tolerance or bioavailability of $\mathrm{Cu}$ may be limited by intestinal failure. In addition, the need to ensure delivery of $\mathrm{Cu}$ for patients with severe deficiency may necessitate IV administration. Supplementation should continue until normal serum $\mathrm{Cu}$ concentrations are restored and clinical features resolve. This should be followed by long-term supplementation sufficient to prevent recurrence of deficiency. When $\mathrm{Cu}$ deficiency has occurred for patients treated with $\mathrm{PN}$, serum $\mathrm{Cu}$ concentrations have normalized, and clinical features have improved within 6 weeks of supplementation..$^{21,22,72}$ The hematologic features resolve within about 4 weeks, but neurologic features improve relatively slowly and may be in part irreversible. The rate of resolution of $\mathrm{Cu}$ deficiency is likely to depend on the severity of deficiency, route of supplementation, and $\mathrm{Cu}$ dosage. If features of deficiency do not respond to increased $\mathrm{Cu}$ provision, ZICD should be ruled out.

$\mathrm{Cu}$ dosing should be individualized according to the severity of hypocupremia and clinical features. $\mathrm{Cu}$ is available as MTE products, which typically provide $0.4-1.0 \mathrm{mg} / \mathrm{mL}$, oral tablets ( 2 and $5 \mathrm{mg}$ ), and injection $(0.4-2 \mathrm{mg} / \mathrm{mL}) .^{73}$ Severe $\mathrm{Cu}$ deficiency in adults can be treated with $\mathrm{IV} \mathrm{Cu}(2-4 \mathrm{mg} / \mathrm{d})$ for 6 days, followed by oral $\mathrm{Cu}$ sulfate or gluconate (3-8 $\mathrm{mg} / \mathrm{d}){ }^{36} \mathrm{In}$ a reported case of severe $\mathrm{Cu}$ deficiency, it was possible, following IV $\mathrm{Cu}$ supplementation, to maintain the serum $\mathrm{Cu}$ concentration in the reference range by high-dose oral supplementation ( $8 \mathrm{mg} / \mathrm{d})$, despite loss of absorptive surface area. ${ }^{74}$ This suggests that sufficient absorption may be achieved by supersaturation of the remaining $\mathrm{Cu}$ transport capacity. ${ }^{75}$

When $\mathrm{Cu}$ deficiency occurs during $\mathrm{EN}$, there are various treatment options. Enteral $\mathrm{Cu}$ provision can be increased by giving either pharmaceutic $\mathrm{Cu}$ products or cocoa powder, of which $100 \mathrm{~g}$ contains $3.61-3.79 \mathrm{mg}$ of $\mathrm{Cu}^{76}$ In practice, daily doses of 10-40 $\mathrm{g}$ of cocoa powder have been used ${ }^{31}$ that, in this study, were reported to deliver $\mathrm{Cu}$ doses of 1.36-2.56 mg/d. Clinicians should be aware that $\mathrm{Cu}$ may be poorly absorbed when given through a jejunostomy tube. ${ }^{77}$ If necessary, IV $\mathrm{Cu}$ can be given. It is advisable to monitor $\mathrm{Cu}$ status for patients on long-term EN. 


\section{Cu Toxicity}

Patients with acute $\mathrm{Cu}$ toxicity present with vomiting, diarrhea, and abdominal pain and, if more severe, hepatic necrosis, renal failure, encephalopathy, and death. ${ }^{78}$ Acute toxicity has been reported following consumption of $\mathrm{Cu}$-contaminated water but would be unlikely to occur during PN, unless an error resulted in overdose. For patients treated with long-term PN, there is concern about hepatotoxicity resulting from chronic hepatic accumulation of $\mathrm{Cu}$ in PN-associated liver disease (PNALD). Accumulation may occur if biliary excretion of $\mathrm{Cu}$ is impaired, either because of immaturity of excretory mechanisms or because of cholestasis. Overload may be exacerbated by excessive provision of $\mathrm{Cu}$ resulting from inappropriately formulated MTE products, contamination of PN, or additional intake from other sources.

There is extensive evidence that hepatic $\mathrm{Cu}$ accumulation occurs in PNALD. This is usually at concentrations below the diagnostic threshold for Wilson disease (WD) - that is, $<250$ $\mu \mathrm{g} / \mathrm{g}$, dry weight (reference range, $<35 \mu \mathrm{g} / \mathrm{g}$ ). ${ }^{79,80}$ In 2005, Blaszyk et al measured hepatic $\mathrm{Cu}$ concentrations for patients treated with long-term PN who had abnormal liver enzymes and for control subjects who had drug-induced cholestasis. ${ }^{81} \mathrm{In}$ $89 \%$ of PN patients, hepatic $\mathrm{Cu}$ was $>35 \mu \mathrm{g} / \mathrm{g}$ and in $29 \%$, $>250 \mu \mathrm{g} / \mathrm{g}$ (range, 10-2248). Hepatic $\mathrm{Cu}$ was also increased in the control subjects. It did not correlate with the serum $\mathrm{Cu}$ concentration or duration of PN. These findings suggest that cholestasis is the main causal factor in hepatic $\mathrm{Cu}$ accumulation for patients treated with PN, but they do not exclude the possibility that excessive provision is harmful. Given that about $30 \%$ of adult patients receiving long-term PN develop PNALD, the results from this small study, if typical of the PN population, suggest that about $10 \%$ of adults on long-term PN have significant hepatic $\mathrm{Cu}$ accumulation. An autopsy study of tissue TE concentrations was carried out in 8 adults with short bowel treated with long-term PN, compared with 45 control subjects on oral diet who had not suffered from GI disease. ${ }^{82}$ $\mathrm{Cu}$ dosing was in accordance with 1979 recommendations, ${ }^{83}$ the mean daily dose being $1.4 \mathrm{mg}$ for 14 years. Cu concentrations were increased in liver and kidney specimens from patients receiving PN, being highest $(>250 \mu \mathrm{g} / \mathrm{g})$ in 2 who died of liver failure.

While the clinical outcome in PNALD appears to be poor for patients with severe hepatic $\mathrm{Cu}$ accumulation, it is unclear whether the $\mathrm{Cu}$ is directly hepatotoxic. Various observations suggest that $\mathrm{Cu}$ accumulation may be harmful. Supraphysiologic concentrations of $\mathrm{Cu}$ are known to be pro-oxidant, generating reactive oxygen species that can cause oxidative damage to macromolecules. ${ }^{78}$ In addition, $\mathrm{Cu}$ accumulation in WD is hepatotoxic, neurotoxic, and nephrotoxic. ${ }^{79,84}$ However, PNALD and WD are not directly comparable, because they have different causes and clinical features and the extent to which $\mathrm{Cu}$ causes harmful oxidative effects in vivo in PNALD is unknown, as are its macromolecular targets. ${ }^{85}$ Moreover, the observation that neonates tolerate high hepatic $\mathrm{Cu}$ concentrations without adverse effects suggests that $\mathrm{Cu}$ accumulation per se is not necessarily harmful. ${ }^{86}$ Whether $\mathrm{Cu}$ is hepatotoxic may depend on factors other than its total hepatic concentration, including its subcellular location and extent of protein binding. It has also been suggested that $\mathrm{Zn}$ decreases the hepatotoxicity of $\mathrm{Cu}$ in $\mathrm{WD},{ }^{87}$ but whether it does so in PNALD is unknown. Until the results of further research clarify whether $\mathrm{Cu}$ is hepatotoxic in PNALD, $\mathrm{Cu}$ should be considered potentially harmful for patients treated with long-term PN. Chronic $\mathrm{Cu}$ toxicity is also implicated in atherosclerosis and neurodegenerative diseases, including Alzheimer's disease and Parkinson's disease. ${ }^{88}$

\section{Assessment of Cu Status}

\section{Serum $\mathrm{Cu}$}

All currently available biomarkers of $\mathrm{Cu}$ status are unreliable. The serum $\mathrm{Cu}$ concentration is the most useful and most frequently ordered test, but its limitations need to be considered. ${ }^{89}$ When interpreting individual results, the clinician should first consider how reliably this can be done through the population reference range. Second, when interpreting serial results, the clinician must decide whether a change between consecutive results is significant, possibly requiring clinical intervention, or can be accounted for by a combination of biological variation and analytic imprecision. Regarding use of the reference range, serum $\mathrm{Cu}$ has an index of individuality of 0.41 , which is low (ie, a ratio of intraindividual variation to interindividual variation).$^{90}$ Consequently, results within the reference range do not exclude the possibility that there has been a diseaserelated change in concentration that is highly significant for the individual. Unless a previous result is available for comparison, the clinician will be unaware of the significance of the result. Clearly, this low index of individuality decreases the value of the population reference range for interpreting individual serum $\mathrm{Cu}$ results. Regarding serial results, critical difference values can help clinicians interpret the significance of changes. Serum $\mathrm{Cu}$ has been reported to have a critical difference of $2.3 \mu \mathrm{mol} / \mathrm{L}(14.6 \mu \mathrm{g} / \mathrm{L})$, suggesting that a relatively small change between consecutive results is likely to be significant. ${ }^{90}$ Critical differences should ideally be determined by all clinical laboratories because the values are influenced by analytic imprecision, which varies among laboratories. ${ }^{91}$

The serum $\mathrm{Cu}$ concentration is insensitive to deficiency, tending to remain within the reference range except in severe deficiency. A normal or increased serum $\mathrm{Cu}$ result does not therefore rule out deficiency. ${ }^{15}$ It is also insensitive to hepatic $\mathrm{Cu}$ accumulation, tending to plateau once requirements are met and correlating poorly with tissue accumulation. ${ }^{14,81,82}$ The lack of correlation with $\mathrm{Cu}$ status makes serum $\mathrm{Cu}$ an unreliable test for guiding supplementation of $\mathrm{PN}$, except at extremes. $^{92}$ Hypocupremia can occasionally occur in the absence of deficiency (eg, for patients with WD) ${ }^{93}$ When the 
cause of hypocupremia is uncertain, WD can be ruled out by the finding of a 24-hour urinary $\mathrm{Cu} \leq 0.6 \mu_{\mathrm{mol}}{ }^{94}$

Confounding factors cause serum $\mathrm{Cu}$ to increase in the absence of $\mathrm{Cu}$ excess, the most common being the APR, during which proinflammatory cytokines stimulate the synthesis of $\mathrm{Cp}$ irrespective of $\mathrm{Cu}$ status. Indeed, hypercupremia is to be expected in hospitalized patients with trauma or infection or in those who are postsurgical. ${ }^{95}$ A recent retrospective review of $\mathrm{Cu}$ status in hospitalized patients treated with $\mathrm{PN}$ observed that serum $\mathrm{Cu}$ correlated with $\mathrm{C}$-reactive protein concentrations $>4$ $\mathrm{mg} / \mathrm{dL}(P=.03){ }^{20}$ This APR-associated increase in serum $\mathrm{Cu}$ concentrations can mask deficiency ${ }^{2}$ or cause unnecessary concern about toxicity, either of which could result in inappropriate clinical action. In addition, serum $\mathrm{Cu}$ concentrations measured for monitoring the treatment of deficiency should be interpreted with caution if there is a concurrent APR. Cp synthesis is also stimulated by estrogens, resulting in increased serum $\mathrm{Cu}$ concentrations among women who are pregnant or taking estrogens. In the presence of these confounding factors, serum $\mathrm{Cu}$ concentrations within the reference range do not exclude deficiency, but hypocupremia is consistent with a diagnosis of $\mathrm{Cu}$ deficiency. ${ }^{14,15,96,97}$

It is advantageous to measure the $\mathrm{Cp}$ concentration when measuring serum $\mathrm{Cu}$. Both increase in parallel because their concentrations are approximately linearly related. Any increase in $\mathrm{Cu}$ caused by a confounding factor will then be readily apparent. To allow for changes in $\mathrm{Cp}$ caused by age, sex, or inflammation, authors have suggested routinely adjusting serum $\mathrm{Cu}$ for the $\mathrm{Cp}$ concentration $^{98}$ or calculating the $\mathrm{Cu}: \mathrm{Cp}$ ratio. ${ }^{99}$ Laboratories should determine their own adjustment equation or ratio because these depend on the methods used and population studied. ${ }^{100}$

\section{Cuproproteins}

Many cuproproteins other than $\mathrm{Cp}$ have been investigated as possible markers of $\mathrm{Cu}$ status, but none reliably detect early deficiency or toxicity. ${ }^{5,101}$ Assays are unstandardized, necessitating that individual laboratories determine local reference ranges. These tests are also subject to high intraindividual variation. Lability of cuproenzymes may necessitate rapid specimen processing, confining analysis to hospitalized patients. There is also limited information available on the diagnostic sensitivity and specificity of these tests.

Superoxide dismutase in red blood cells is considered a relatively sensitive marker of $\mathrm{Cu}$ deficiency, decreasing in $\mathrm{Cu}$ deficiency and in subjects with low $\mathrm{Cu}$ intake, but the change occurs slowly because of slow turnover of red blood cells. ${ }^{102}$ Plasma diamine oxidase decreases in $\mathrm{Cu}$-deficient subjects but has limited use in diagnosis because it increases during tissue injury. Studies have also investigated platelet cytochrome $\mathrm{C}$ oxidase as a biomarker of $\mathrm{Cu}$ status, but it is limited by lability and high interindividual variation. Neither marker is routinely measured in clinical practice. These are discussed in detail elsewhere. ${ }^{4,89}$

$\mathrm{Cu}$ chaperone for superoxide dismutase (CCS) is the most promising potential biomarker of $\mathrm{Cu}$ status. In humans, mononuclear cell mRNA for CCS increases in malnourished $\mathrm{Cu}$-deficient patients and decreases in response to $\mathrm{Cu}$ supplementation. ${ }^{102,103}$ A recent study observed that neither CCS protein nor mRNA transcripts were influenced by inflammatory status, supporting their use as biomarkers of $\mathrm{Cu}$ status. ${ }^{104}$

\section{Liver $\mathrm{Cu}$}

The most reliable indicator of $\mathrm{Cu}$ status is liver $\mathrm{Cu}$ concentration, but this has limitations. ${ }^{97}$ First, underestimation may result from inhomogeneous distribution of $\mathrm{Cu} .{ }^{105}$ Second, liver biopsy may be unsafe or contraindicated for some patients and is not feasible to repeat frequently, because of its invasive nature. A recently established technique called laser ablationinductively coupled plasma-mass spectrometry has been used to measure liver $\mathrm{Cu}$ concentrations. ${ }^{106}$ It is more accurate, quicker, and cheaper than standard metal deposit measurement and can simultaneously measure $\mathrm{Zn}$ and selenium. When applied to liver specimens from patients with WD, it has confirmed that hepatic $\mathrm{Cu}$ is inhomogeneously distributed, but the technique has not yet been applied to PNALD. The prognostic value of this method is worthy of assessment, but ideally, hepatic $\mathrm{Cu}$ would be measured noninvasively. This may eventually be possible through imaging techniques. ${ }^{101}$

\section{Metabolomics and Transcriptomics}

Clinically useful biomarkers of micronutrient status may be identified by using -omics techniques to detect changes in response to supplementation. ${ }^{107}$ As yet, few such approaches have been described in relation to $\mathrm{Cu}$ status. A recent study of proteins correlating with micronutrient status in undernutrition unexpectedly identified a Ras protein that explained variation in plasma $\mathrm{Cu}$ concentration additional to that explained by $\mathrm{Cp}$. This protein merits further investigation as a biomarker of $\mathrm{Cu}$ status. ${ }^{108}$ A network of proteins representing the $\mathrm{Cu}$ interactome identified ATPases 7A and 7B as proteins worthy of further assessment as markers of $\mathrm{Cu}$ status. ${ }^{102}$

There is a clinical need for biomarkers, ideally measurable in peripheral blood, that can detect $\mathrm{Cu}$ accumulation before the onset of clinical features. Studies in animals have shown that -omics approaches can sensitively detect $\mathrm{Cu}$ toxicity by observing genetic and metabolic changes. A transcriptomics approach observed downregulation of genes associated with cholesterol synthesis, as in a mouse model of WD, and upregulation of metallothionein and catalase. ${ }^{109} \mathrm{~A}$ metabolomics approach identified a metabolic signature of $\mathrm{Cu}$ exposure. ${ }^{110}$ These techniques have not yet been applied to the study of $\mathrm{Cu}$ exposure in humans. At present it is difficult to predict which patients are 
Table 1. Parenteral Copper Requirements in Adults.

\begin{tabular}{lcc}
\hline $\begin{array}{l}\text { Condition: } \\
\text { Requirement, mg/d }\end{array}$ & Year & Reference \\
\hline Stable & & \\
$0.5-1.5$ & 1979 & 83 \\
$0.3-0.5$ & 2002 & 112 \\
$317-518^{\mathrm{a}}$ & 2014 & 113 \\
Diarrhea: $0.4-0.5$ & 1981 & 92 \\
Cholestasis: 0.15 & 1981 & 92 \\
\hline
\end{tabular}

${ }^{\mathrm{a}}$ Values in $\mu \mathrm{g} / \mathrm{d}$.

susceptible to $\mathrm{Cu}$ accumulation, but the ability to do this could guide $\mathrm{Cu}$ provision. Gene testing may have predictive value because it is likely that genetic factors contribute to interindividual variation in the effects of $\mathrm{Cu}$ exposure. For example, individuals who are heterozygous for ATP7B mutations for WD may be predisposed to liver disease when exposed to excess $\mathrm{Cu}$ during long-term PN. The carrier frequency for these genes is relatively common at 1 in $90 .{ }^{111}$ These are all key areas for future research.

\section{Practical Considerations}

\section{Standard Requirements}

In 1979 the American Medical Association published recommendations on $\mathrm{Cu}$ supplementation of $\mathrm{PN}$ based on knowledge of oral intake and estimated absorption of $\mathrm{Cu}$ from a normal diet. $^{83}$ The amount recommended for adults was $0.5-1.5 \mathrm{mg} / \mathrm{d}$. Subsequently, the results of $\mathrm{Cu}$ balance studies suggested that the dose should be lower. ${ }^{92}$ In response to this, the American Society for Parenteral and Enteral Nutrition (ASPEN) changed the standard recommendation to $0.3-0.5 \mathrm{mg} / \mathrm{d}$, which has remained unchanged since $2002^{112}$ (Table 1). The European Society for Clinical Nutrition and Metabolism (ESPEN) made the same recommendation in its guidance on perioperative PN. ${ }^{114}$ These recommendations were supported by a recently published systematic review of TE supplementation in PN. ${ }^{115}$

\section{Individualization of Cu Provision}

Standard recommendations should be considered a starting point for estimating individual requirements and adjusting $\mathrm{Cu}$ provision accordingly. However, studies suggest that in practice this is poorly done. A 2013 Canadian review of 135 patients treated with long-term $\mathrm{PN}$ observed that $\mathrm{Cu}$ supplementation was $0.64 \pm 0.35 \mathrm{mg} / \mathrm{d}$, exceeding the standard recommendation. ${ }^{116}$ Supplementation did not appear to be influenced by factors such as the GI anatomy of individual patients or indication for PN. This failure to adjust $\mathrm{Cu}$ provision risks causing deficiency or toxicity. Similarly, a retrospective observational study of TE status and dosing among 26 adult patients treated with long-term $\mathrm{PN}$ reported that $95.5 \%$ of $\mathrm{Cu}$ doses delivered exceeded the standard recommendation. ${ }^{117} \mathrm{Cu}$ doses of $1 \mathrm{mg} / \mathrm{d}$ resulted in hypercupremia in $22.5 \%$ of the tests performed. The excessive $\mathrm{Cu}$ dosing observed in these studies is in part a consequence of inappropriately formulated MTE products.

In practice, prescribers have insufficient information to enable them to fully individualize $\mathrm{Cu}$ doses. This would require knowledge of the patient's $\mathrm{Cu}$ status, the disease-specific requirements, and the amount of bioavailable $\mathrm{Cu}$ already present in the PN and other sources. Nevertheless, individual clinical circumstances should be carefully assessed and $\mathrm{Cu}$ provision adjusted if necessary. In what follows, situations are considered in which individual requirements may differ from the standard recommendation. The discussion is confined to $\mathrm{Cu}$, but in practice all micronutrients should be considered together.

Increased requirements. $\mathrm{Cu}$ requirements increase for patients with prolonged, increased GI losses or persistent malabsorption. ${ }^{16,118}$ In this situation, it may be appropriate to give higher doses of $\mathrm{Cu}$. Balance studies have suggested that patients with persistent diarrhea (GI secretions $>300 \mathrm{~g} / \mathrm{d}$ ) require $0.4-0.5 \mathrm{mg} / \mathrm{d}$ to maintain balance (ie, doses at the upper end of the standard recommendation). ${ }^{92}$ This study investigated patients receiving total $\mathrm{PN}$. In practice, however, many patients with short bowel take some oral diet, the effect of which on parenteral $\mathrm{Cu}$ requirement is difficult to predict. Oral diet resulting in net $\mathrm{Cu}$ absorption will decrease the requirement. However, oral diet also stimulates the production of $\mathrm{Cu}$-containing secretions, potentially resulting in net $\mathrm{Cu}$ loss and an increased requirement. In practice the net effect of oral diet on parenteral $\mathrm{Cu}$ requirement is unknown because it is not feasible to carry out balance studies with individual patients.

The observations of high exudative $\mathrm{Cu}$ losses for patients with severe burns suggest that $\mathrm{Cu}$ requirements are likely to increase in these patients. ASPEN has recommended higher $\mathrm{Cu}$ provision in this situation. ${ }^{73}$ ESPEN has recommended increasing provision 5 -fold $(3.0-3.5 \mathrm{mg} / \mathrm{d})$ especially while wounds remain open. ${ }^{119}$ Higher $\mathrm{Cu}$ doses may also be required to replace dialysate losses for patients treated with continuous renal replacement therapy. ${ }^{46}$ Increased $\mathrm{Cu}$ provision should also be considered for patients treated with cisplatin. ${ }^{48}$ Clearly, higher doses are required for patients with $\mathrm{Cu}$ deficiency. If deficiency is suspected, it may be appropriate to increase $\mathrm{Cu}$ supplementation to provide at least $1.0 \mathrm{mg} / \mathrm{d}$ in PN. ${ }^{16}$

Decreased requirements. Various publications suggest that for critically ill patients the amount of $\mathrm{Cu}$ that would be required in PN is decreased. ESPEN recommends that, except for patients with severe burns, parenteral $\mathrm{Cu}$ requirements are below the amount provided by currently available MTE products. ${ }^{119}$ Elsewhere, authors have recommended against delivery of $\mathrm{Cu}$ to 
Table 2. Practical Assessment of Cu Status During Parenteral Nutrition.

\begin{tabular}{ll}
\hline Assessment & \multicolumn{1}{c}{ Rationale } \\
\hline $\begin{array}{l}\text { Clinical workup } \\
\text { History } \\
\text { Examination }\end{array}$ & $\begin{array}{l}\text { Elicit possible causes and consequences of Cu deficiency and toxicity. } \\
\text { Elicit anemia, poor wound healing, and neurologic abnormalities, which may occur in deficiency. Features } \\
\text { of liver disease may occur in PNALD. }\end{array}$ \\
$\begin{array}{l}\text { Biochemistry (serum) } \\
\mathrm{Cu}\end{array}$ & $\begin{array}{l}\text { Hypocupremia is consistent with Cu deficiency. } \\
\mathrm{Cp}\end{array}$ \\
$\mathrm{CRP}$ & Assists with interpretation of serum Cu results. \\
$\mathrm{Zn}$ & Overprovision of enteral or oral $\mathrm{Zn}$ can cause Cu deficiency. \\
$\mathrm{Fe}$ status & Fe deficiency may coexist with Cu deficiency. \\
$\mathrm{Vitamin} \mathrm{B}_{12}, \mathrm{D}, \mathrm{E}$ & Vitamin deficiency may coexist with Cu deficiency. \\
Full blood picture & Microcytic or normocytic anemia and neutropenia can occur in Cu deficiency. \\
Liver Cu & Confirmation of Cu accumulation. \\
Bone imaging & Osteoporosis can occur in Cu deficiency. \\
\hline
\end{tabular}

APR, acute phase response; $\mathrm{Cp}$, ceruloplasmin; CRP, C-reactive protein; $\mathrm{Cu}$, copper; Fe, iron; PNALD, parenteral nutrition-associated liver disease; $\mathrm{Zn}$, zinc.

critically ill patients at doses $>1.2 \mathrm{mg} / \mathrm{d}^{120}$ In a study of $\mathrm{Cu}$ provision for critically ill patients treated with $\mathrm{PN}$, doses of 0.3 $\mathrm{mg} / \mathrm{d}$ were sufficient to maintain constant serum $\mathrm{Cu}$ concentrations. ${ }^{121}$ In consideration of these recommendations, it should be remembered that critical illness encompasses a diverse range of conditions and disease severities.

It may be necessary to decrease $\mathrm{Cu}$ provision for patients with cholestasis. A difficulty in practice is that cholestasis is difficult to quantitate and its severity varies widely. Ideally, it would be quantitated by direct measurement of bile flow, but this cannot be done in clinical practice. Clinicians therefore have to rely on surrogate measures and the presence of clinical features. Cholestasis can be considered to be present if there is direct (conjugated) hyperbilirubinemia with (1) direct bilirubin $>1 \mathrm{mg} / \mathrm{dL}$ when total bilirubin is $<5 \mathrm{mg} / \mathrm{dL}$ or (2) direct bilirubin $>20 \%$ of total bilirubin when it is $>5 \mathrm{mg} / \mathrm{dL}^{3}$

Limited data are available on which to base guidance on parenteral $\mathrm{Cu}$ provision for patients with cholestasis. However, the observations of liver $\mathrm{Cu}$ accumulation for patients with cholestasis suggest that caution is necessary. ${ }^{81,82}$ Howard et al recommended that $\mathrm{Cu}$ be withheld once liver aminotransferase and alkaline phosphatase levels increase to twice that of reference values and before serum bilirubin levels increase. ${ }^{82}$ ASPEN has recommended decreasing or withholding $\mathrm{Cu}$ provision for patients with significant cholestasis or liver disease. ${ }^{73}$ On the basis of balance studies, a dose of $0.15 \mathrm{mg} / \mathrm{d}$ has been suggested. ${ }^{92}$ Doses below this, if continued indefinitely, risk the development of deficiency. This contention is supported by the reports of severe $\mathrm{Cu}$ deficiency occurring for patients with cholestasis after $\mathrm{Cu}$ has been withheld from $\mathrm{PN} .{ }^{21,22}$ The risk of deficiency would be expected to be higher if GI losses increase or if there is high $\mathrm{Zn}$ provision. To avoid the development of $\mathrm{Cu}$ deficiency for patients with cholestasis, it may be preferable to decrease $\mathrm{Cu}$ provision rather than to withhold it altogether.
Whether decreased or withheld, $\mathrm{Cu}$ provision should be kept under close review because individual requirements may change.

\section{Monitoring of Cu Status}

Serum $\mathrm{Cu}$ should be measured regularly for patients treated with long-term $\mathrm{PN}$ and in any patient in whom $\mathrm{Cu}$ deficiency is suspected. There are limited data available to guide the frequency of measurements, the recommendations being based on expert opinion. ESPEN guidelines on home PN recommend measuring serum $\mathrm{Cu}$ every 6 months. ${ }^{122}$ The frequency of measurements should be increased for patients who are clinically unstable. ${ }^{123}$ A recent study of TE monitoring among critically ill patients observed that significant cost savings could be made by targeting the sickest patients for monitoring, as opposed to automatic testing of all patients. ${ }^{124}$ For patients with cholestasis supplemented with $\mathrm{Cu}$ provided by a standard MTE product, 6-monthly monitoring of $\mathrm{Cu}$ should suffice, ${ }^{16}$ but 3-monthly monitoring has been recommended for patients with increased total bilirubin attributed to liver disease. ${ }^{125}$ For patients treated with $\mathrm{PN}$ from which supplemental $\mathrm{Cu}$ has been withheld, monthly monitoring has been recommended to facilitate early detection of $\mathrm{Cu}$ deficiency. ${ }^{16,125}$

Serum $\mathrm{Cu}$ results should be considered in the clinical context and along with the results of other investigations. Factors to consider in the practical assessment of $\mathrm{Cu}$ status are summarized in Table 2. Causes and features of $\mathrm{Cu}$ deficiency should be sought and C-reactive protein measured to assess the APR. ${ }^{113}$ If $\mathrm{Cu}$ deficiency is suspected, a full blood picture should be ordered, to exclude hematologic features of deficiency, and a trial of supplementation considered. ${ }^{22,72}$ Resolution of features in response to supplementation may help to confirm the diagnosis. Serum $\mathrm{Zn}$ should be measured during long-term PN to exclude $\mathrm{Zn}$ excess. Zn excess can also 
be excluded by 24 -hour urine $\mathrm{Zn}<19 \mu \mathrm{mol}^{40}{ }^{40}$ Vitamin $\mathrm{B}_{12}$ status should be assessed, especially after gastric surgery. Its deficiency may coexist with that of $\mathrm{Cu}$, as can deficiencies of $\mathrm{Fe}$ and vitamins $\mathrm{D}$ and $\mathrm{E}$. If $\mathrm{Cu}$ accumulation is suspected, features of cholestatic liver disease should be sought and liver function tests measured. Liver biopsy may be considered to measure the liver $\mathrm{Cu}$ concentration.

\section{$\mathrm{Cu}$ Contamination}

Contamination of PN with $\mathrm{Cu}$ may result in excessive delivery of $\mathrm{Cu}$. One study that examined 8 component solutions observed that $\mathrm{Cu}$ was 1 of 12 TEs present in amounts $>1 \mu \mathrm{g} / \mathrm{L}$ in every solution. ${ }^{126} \mathrm{Cu}$ was a minor contaminant present in PN at a final concentration of $82 \mu \mathrm{g} / 2 \mathrm{~L}$. Cu was present as a contaminant in the amino acid solutions and sterile water but not in potassium chloride, sodium chloride, and calcium gluconate solutions. More recently, $\mathrm{Cu}$ was reported as a contaminant from 5 of 14 PN components undeclared on the product label. ${ }^{127}$ The actual amount of $\mathrm{Cu}$ was estimated to exceed the prescribed amount by $7 \%-426 \%$. The total $\mathrm{Cu}$ contamination of a PN regimen depends on the volume of individual components added and has been reported to range from 0.1-0.4 $\mathrm{mg} / \mathrm{d} .^{15}$ Patients treated with PN may receive $\mathrm{Cu}$ in other IV fluids, causing the total amount delivered to greatly exceed the amount prescribed. Contamination is highest in blood products such as packed red blood cells and frozen plasma and in albumin solutions $(0.5 \mathrm{mg} / \mathrm{L})$ and crystalloids $(0.14 \mathrm{mg} / \mathrm{L}) .{ }^{128}$ Berger and Cavadini estimated that critically ill patients, with burns or trauma who were treated with large volumes of these fluids, received $\mathrm{Cu}$ doses 2.3 times the RDA. ${ }^{128}$

The inadvertent delivery of $\mathrm{Cu}$ raises safety concerns. Whether safety is compromised depends on the individual clinical circumstances and on the amount of $\mathrm{Cu}$ delivered. The concerns are greatest for patients with cholestasis who are treated with long-term PN. ASPEN has recommended that $\mathrm{Cu}$ contamination of composite PN regimens delivered to adults should not exceed $0.1 \mathrm{mg} / \mathrm{d}^{73}$ To achieve this target, all components of PN should be considered.

\section{Stability Considerations}

Unwanted interactions among components of PN can result in precipitation or degradation of micronutrients. $\mathrm{Cu}$ has been reported to interact with cysteine to form precipitates that are trapped by the filter, thereby decreasing the bioavailability of both nutrients. The mechanism of precipitation is uncertain, but spectroscopic examination of precipitates recently identified $\mathrm{Cu}$ and sulfur as the main elements. ${ }^{129} \mathrm{Cu}$ may react directly with cysteine to form $\mathrm{Cu}$ cysteinate. Alternatively, it may react with hydrogen sulfide, formed from cysteine by heat sterilization, to form $\mathrm{Cu}$ sulfide ${ }^{130}$ The probability of precipitation is highest at high concentrations of both nutrients, the $\mathrm{Cu}$ concentration in one reported case being 170 $\mu \mathrm{g} / \mathrm{L} .{ }^{131}$ It may also be influenced by the timing of additions. When cysteine was added to PN immediately before infusion, no significant differences were observed between prefilter and postfilter concentrations of $\mathrm{Cu}$ and cysteine, nor was there visible precipitation. ${ }^{132}$ The authors concluded that L-cysteine added to PN immediately before infusion is stable over 24 hours of infusion. This interaction can be prevented by omission of $\mathrm{Cu}$ from $\mathrm{PN}$, but this is impractical. Instead, limiting the $\mathrm{Cu}$ concentration to $157 \mu \mathrm{g} / \mathrm{L}$ with the use of low-pH cysteine-containing amino acid solutions has been suggested. ${ }^{133}$ When $\mathrm{Cu}$ requirements are high, it may be necessary to deliver some or all of the $\mathrm{Cu}$ by a separate IV infusion. The feasibility of providing $\mathrm{Cu}$ enterally should also be considered.

Ascorbic acid is the biologically active form of vitamin C. It is an unstable component of PN, being reversibly oxidized anaerobically to dehydroascorbic acid that, in the presence of oxygen and $\mathrm{Cu}$, is irreversibly oxidized to inactive diketogulonic acid. ${ }^{134}$ This is then further oxidized to oxalate. The oxygen for this reaction reaches PN either in component solutions or by permeation through the wall of the bag. Ascorbate can be protected during storage of $\mathrm{PN}$ by using multilayered bags that are less permeable to oxygen. ${ }^{135,136}$ As new PN regimens are developed, the potential for interaction of components with $\mathrm{Cu}$ should be considered.

\section{MTE Products}

It is difficult for prescribers to comply with the current ASPEN recommendations on $\mathrm{Cu}$ provision in $\mathrm{PN}$ because of the formulation of most MTE products currently available in the United States and Europe. These products provide up to twice the recommended amount of $\mathrm{Cu}$, which exceeds most patients' requirements, and a recent review concluded that they were potentially toxic. ${ }^{73}$ Moreover, the formulation of these products is not conducive to individualization of $\mathrm{Cu}$ dosing. When prescribers wish to decrease or withhold $\mathrm{Cu}$, the MTE product must be withheld and the $\mathrm{PN}$ regimen supplemented individually with the necessary doses of $\mathrm{Cu}$, selenium, and $\mathrm{Zn}$. When $\mathrm{Cu}$ provision is being increased, it is not safe to increase the MTE dosage, because this could result in excessive provision of manganese and other TEs. In this situation, the PN regimen can be supplemented with an individual $\mathrm{Cu}$ product, unless stability considerations demand that the $\mathrm{Cu}$ be delivered by a separate IV infusion. These approaches are costly and labor intensive and increase the risk of errors.

ASPEN has made a call to action to bring safer products to the market, recommending that $\mathrm{Cu}$ doses provided by adult parenteral MTE products are decreased to $0.3-0.5 \mathrm{mg} / \mathrm{d}^{137}$ Similarly, the Australasian Society for Parenteral and Enteral Nutrition has recommended that $\mathrm{Cu}$ dosing in MTE products, for the Australian and New Zealand market, be decreased to 315 $\mu \mathrm{g} / \mathrm{d} .{ }^{113} \mathrm{In}$ addition, there may be a place for low-Cu MTE products for use among patients whose requirements are below the standard recommendations. Ideally, a range of products should 
be developed with doses of $\mathrm{Cu}$ and other TEs appropriate for situations commonly encountered in practice. The availability of such products would greatly facilitate individualization of $\mathrm{Cu}$ provision. There is also a need for pharmaceutic companies to routinely provide information on $\mathrm{Cu}$ contamination-in PN products and other IV fluids as well. The availability of this information would inform decisions on supplementation.

ASPEN has provided guidance on managing product shortages, ${ }^{26,138}$ summarized briefly here. Most important, supplies should be reserved for the most vulnerable patients - namely, those with existing deficiency or at high risk of developing deficiency if micronutrients are withheld. TEs should be supplemented orally for patients with sufficient GI absorptive capacity. Rationing may be necessary - for example, by delivering standard doses 3 times weekly rather than daily or by providing daily delivery of half the standard dose. If rationing is necessary, clinicians should be alert to possible deficiencies and should monitor patients accordingly. Supplies should be sought for micronutrients, including $\mathrm{Cu}$, for which deficiency is likely to occur if the micronutrient is withheld. Advice on strategic planning for future shortages is available elsewhere. ${ }^{139}$

\section{Future Directions}

Prescribers of micronutrients should aspire to individualize provision. However, much research and development will be necessary before true individualization of $\mathrm{Cu}$ provision is possible. More information is required on the $\mathrm{Cu}$ provision required to maintain optimal status in different diseases, especially critical illness. Sensitive and specific biomarkers of $\mathrm{Cu}$ status will need to be developed, enabling mild derangements in $\mathrm{Cu}$ status to be detected and provision to be adjusted before the onset of clinical features. It is likely that new tests will emerge from studies using -omics technologies or from studies of the effects of $\mathrm{Cu}$ deficiency on physiologic systems such as the immune system. The availability of better tests of $\mathrm{Cu}$ status will decrease the uncertainty that affects decisions on $\mathrm{Cu}$ provision in $\mathrm{PN}$. It will also facilitate the study of marginal $\mathrm{Cu}$ deficiency in hospitalized patients and in the general population. There is an urgent need for a range of appropriately formulated MTE products to be developed, both to enable compliance with the 2012 ASPEN recommendations and to facilitate adjustment of parenteral $\mathrm{Cu}$ doses.

\section{Statement of Authorship}

C. Livingstone conceived and drafted this article, gave final approval, and agrees to be accountable for all aspects of work ensuring integrity and accuracy.

\section{References}

1. Karpel JT, Peden VH. Copper deficiency in long term parenteral nutrition. J Pediatr. 1972;80:32-36

2. Collins JF, Klevay LM. Copper. Adv Nutr.2011;2:520-522.
3. Blackmer AB, Bailey E. Management of copper deficiency in cholestatic infants: review of the literature and a case series. Nutr Clin Pract. 2013;28:75-86.

4. Danzeisen R, Araya M, Harrison B, et al. How reliable and robust are current biomarkers for copper status? Br J Nutr. 2007;98:676-683.

5. Failla ML, Hopkins RG. Is low copper status immunosuppressive? Nutr Rev. 1998;56:S59-S64.

6. Percival SS. Copper and immunity. Am JClin Nutr. 1998;67:1064S-1068S.

7. Djoko KY, Ong CL, Walker MJ, McEwan AG. The role of copper and zinc toxicity in innate immune defense against bacterial pathogens. $J$ Biol Chem. 2015;290:18954-18961.

8. Hodgkinson V, Petris MJ. Copper homeostasis at the host-pathogen interface. J Biol Chem. 2012;287:13549-13555.

9. Collins JF, Prohaska JR, Knutson MD. Metabolic crossroads of iron and copper. Nutr Rev. 2010;68:133-147.

10. Johnson MA, Fisher JG, Kays SE. Is copper an antioxidant nutrient? Crit Rev Food Sci Nutr. 1992;32:1-31.

11. Institute of Medicine. Copper. In: Food and Nutrition Boards, ed. Dietary Reference Intakes: Vitamin A, Vitamin K, Arsenic, Boron, Chromium, Copper, Iodine, Iron, Manganese, Molybdenum, Nickel, Silicon, Vanadium and Zinc. Washington, DC: National Acdemy Press; 2002:224-257.

12. Turnlund J, Scott K, Peiffer G, et al. Copper status of young men consuming a low copper diet. Am J Clin Nutr. 1997;65:72-78.

13. Ducros V, Arnaud J, Tahiri M, et al. Influence of short-chain fructooligosaccharides (sc-FOS) on absorption of $\mathrm{Cu}, \mathrm{Zn}$ and $\mathrm{Se}$ in healthy post-menopausal women. $J$ Am Coll Nutr. 2005;24:30-37.

14. Food and Nutrition Board, Institute of Medicine. Dietary Reference Intakes For Vitamin A, Vitamin K, Arsenic, Boron, Chromium, Copper, Iodine, Iron, Manganese, Molybdenum, Nickel, Silicon, Vanadium, and Zinc. Washington, DC: National Academies Press; 2001.

15. Frankel DA. Supplementation of trace elements in parenteral nutrition: rationale and recommendations. Nutr Res. 1993;13:583-596.

16. FesslerTA. Trace elements in parenteral nutrition: a practical guide for dosage and monitoring for adult patients. Nutr Clin Pract. 2013;28:722-729.

17. Vilter RW, Bozian RC, Hess EV, Zellner DC, Ptering HD. Manifestations of copper deficiency in a patient with systemic sclerosis on intravenous hyperalimentation. N Engl J Med. 1974;291:188-191.

18. Heller RM, Kirchner SG, O'Neill JA, et al. Skeletal changes of copper deficiency in infants receiving prolonged PN. J Pediatr. 1978;92:947-949.

19. Fujita M, Itakura T, Takagi Y, Okada A. Copper deficiency during total parenteral nutrition: clinical analysis of three cases. JPEN J Parenter Enteral Nutr. 1989;13:421-425.

20. McKay M, Mulroy CW, Street J, et al. Assessing copper status in pediatric patients receiving parenteral nutrition. Nutr Clin Pract. 2015;30:117-121.

21. Spiegel JE, Willenbucher F. Rapid development of severe copper deficiency in a patient with Crohn's disease receiving parenteral nutrition. JPEN J Parenter Enteral Nutr. 1999;23:169-172.

22. Fuhrman MP, Herrmann V, Masidonski P, Eby C. Pancytopenia after removal of copper from total parenteral nutrition. JPEN J Parenter Enteral Nutr. 2000;24:361-366.

23. Pramyothin P, Kim DW, Young LS, Wichansawakun S, Apovian CM. Anemia and leukopenia in a long-term parenteral nutrition patient during a shortage of parenteral trace element products in the United States. JPEN J Parenter Enteral Nutr. 2013;37:425-429.

24. Dembinski K, Gargasz AE, Dabrow S, Rodriguez L. Three distinct cases of copper deficiency in hospitalized pediatric patients. Clin Pediatr. 2012;5:759-762.

25. Palm E, Dotson B. Copper and zinc deficiency in a patient receiving long-term parenteral nutrition during a shortage of parenteral trace element products. JPEN J Parenter Enteral Nutr. 2015;39:986-989.

26. Hanson C, Thoene M, Wagner J, Collier D, Lecci K, Anderson-Berry A. Parenteral nutrition additive shortages: the short-term, long-term and potential epigenetic implications in premature and hospitalized infants. Nutrients. 2012;4:1977-1988. 
27. Braga CBM, Ferreira IM, Marchini JS, Cunha SF. Copper and magnesium deficiencies in patients with short bowel syndrome receiving parenteral nutrition or oral feeding. Arq Gastroenterol. 2015;52:94-99.

28. Yang CJ, Duro D, Zurakowski D, Lee M, Jaksic T, Duggan C. High prevalence of multiple micronutrient deficiencies in children with intestinal failure: a longitudinal study. J Pediatr. 2011;159:39-44.

29. Compher C, Boullata JI, Pickett-Blakely OM, Schiavone P, Stoner N, Kinosian BP. Clinical management of patients with parenteral nutritiondependent short bowel syndrome during teduglutide therapy [published online June 25, 2015]. JPEN J Parenter Enteral Nutr.

30. Lim DW, Wales PW, Josephson JK, et al. Glucagon-like peptide 2 improves cholestasis in parenteral nutrition-associated liver disease. JPEN J Parenter Enteral Nutr. 2016;40:14-21.

31. Nishiwaki S, Iwashita M, Goto N, et al. Predominant copper deficiency during prolonged enteral nutrition through a jejunostomy tube compared to that through a gastrostomy tube. Clin Nutr. 2011;30:585-589.

32. Oliver A, Allen KR, Taylor J. Trace element concentrations in patients on home enteral feeding: two cases of severe copper deficiency. Ann Clin Biochem. 2005;42:136-140.

33. Balsa JA, Botella-Carretero JI, Gomez-Martin JM, et al. Copper and zinc levels after derivative bariatric surgery: differences between Roux-en-Y gastric bypass and biliopancreatic diversion. Obes Surg. 2011;21:744-750

34. Kumar P, Hamza N, Madhok B, et al. Copper deficiency after gastric bypass for morbid obesity: a systematic review. Obes Surg. 2016;26:1335-1342.

35. Goodman JC. Neurological complicatons of bariatric surgery. Curr Neurol Neurosci Rep. 2015;15:79.

36. Mechanick JI, Youdim A, Jones DB, et al. Clinical practice guidelines for the perioperative nutritional, metabolic and nonsurgical support of the bariatric surgery patients - 2013 update: cosponsored by American Association of Clinical Endocrinologists, the Obesity Society and American Society for Metabolic and Bariatric Surgery. Endocr Pract. 2013;19:337-372.

37. Duncan A, Yacoubian C, Watson N, Morrison I. The risk of copper deficiency in patients prescribed zinc supplements. J Clin Pathol. 2015;68:723-725

38. Festa DM. Effect of zinc intake on copper excretion and retention in men. Am J Clin Nutr. 1985;41:285-202.

39. Prasad R, Hawthorne B, Durai D, McDowell I. Zinc in denture adhesive: a rare cause of copper deficiency in a patient on home parenteral nutrition [published online October 9, 2015]. BMJ Case Rep.

40. Duncan A, Gallacher G, Willox L. The role of the clinical biochemist in detection of zinc-induced copper deficiency. Ann Clin Biochem. 2016;53:298-301

41. Stargrove MB, Treasure J, McKee DL. Zinc. In: Herb, Nutrient and Drug Interactions: Clinical Implications and Therapeutic Strategies. St Louis, Missouri: Mosby, Elsevier; 2008:618-651.

42. Berger MM, Cavadini C, Bart A. Cutaneous zinc and copper losses in burns. Burns. 1992;18:373-380.

43. Berger MM, Baines M, Raffoul W, et al. Trace element supplementation after major burns modulates antioxidant status and clinical course by way of increased tissue trace element concentrations. Am J Clin Nutr. 2007;85:1293-1300

44. Ohura T, Nakajo T, Okada S, Omura K, Adachi K. Evaluation of effects of nutrition intervention on healing of pressure ulcers and nutritional states (randomized controlled trial). Wound Repair Regen. 2011;19:330-336

45. Berger MM, Eggimann P, Heyland DK, et al. Reduction of nosocomial pneumonia after major burns by trace element supplementation: aggregation of two randomized controlled trials. Crit Care. 2006;10:R153.

46. Berger MM, Shenkin A, Revelly JP, et al. Copper, selenium, zinc and thiamine balances during continuous venovenous hemofiltration in critically ill patients. Am J Clin Nutr. 2004;80:410-416.
47. Nakamura AT, Btaiche IF, Pasko DA, Jain JC, Mueller BA. In vitro clearance of trace elements via continuous renal replacement therapy. $J$ Ren Nutr. 2004;14:214-219.

48. Akutsu Y, Kono T, Uesato M, et al. Are additional trace elements necessary in total parenteral nutrition for patients with esophageal cancer receiving cisplatin-based chemotherapy? Bio Trace Elem Res. 2012;150:109-115.

49. Lozano Herrero J, Munoz Bertran E, Ortega Gonzalez I, Gomez Espin R, Lopez Espin MI. Myelopathy secondary to copper deficiency as a complication of treatment of Wilson's disease. Gastroenterol Hepatol. 2012;35:704-707.

50. Hurwitz M, Garcia MG, Poole RL, Kerner JA. Copper deficiency during parenteral nutrition: a report of four pediatric cases. Nutr Clin Pract. 2004;19:305-308.

51. Wasa M, Satani M, Tanano H, Nezu R, Takagi Y, Okada A. Copper deficiency with pancytopenia during total parenteral nutrition. JPEN $J$ Parenter Enteral Nutr. 1994;18:190-192.

52. Juhasz-Pocsine K, Rudnicki SA, Archer RL, Harik SI. Neurologic complications of gastric bypass surgery for morbid obesity. Neurology. 2007;68:1843-1850.

53. Prodan CI, Bottomley SS, Vincent AS, et al. Copper deficiency after gastric surgery: a reason for caution. Am J Med Sci. 2009;337:256-258.

54. Halfdanarson TR, Kumar N, Li CY, Phyliky RL, Hogan WJ. Hematological manifestations of copper deficiency: a retrospective review. Eur J Haematol. 2008;80:523-531.

55. Klevay LM. Alzheimer's disease as copper deficiency. Med Hypotheses. 2008;70:802-807.

56. Jaiser SR, Winston GP. Copper deficiency myelopathy. J Neurol. 2010;257:869-881.

57. Kumar N, Gross JB, Ahlskog JE. Copper deficiency myelopathy produces a clinical picture like subacute combined degeneration. Neurology. 2004;63:33-39.

58. Kumar N, Ahlskog JE, Klein CJ, Port JD. Imaging features of copper deficiency myelopathy: a study of 25 cases. Neuroradiology. 2006; 48:78-83.

59. Prodan CI, Rabadi M, Vincent AS, Cowan LD. Copper supplementation improves functional activities of daily living in adults with copper deficiency. J Clin Neuromuscul Dis. 2011;12:122-128.

60. Sakamaki Y, Goto K, Watanabe Y, et al. Nephrotic syndrome and endstage kidney disease accompanied by bicytopenia due to copper deficiency. Intern Med. 2014;53:2101-2106.

61. Stec J, Podracka L, Pavkovcekova O, Kollar J. Zinc and copper metabolism in nephrotic syndrome. Nephron. 1990;56:186-187.

62. Marquardt ML, Done SL, Sandrock M, Berdon WE, Feldman KW Copper deficiency presenting as metabolic bone disease in extremely low birth weight, short gut infants. Pediatrics. 2012;130:e695-e698.

63. Hoyle GS, Schwartz RP, Auringer ST. Pseudoscurvy caused by copper deficiency. J Pediatr. 1999;34:161-164.

64. Bonham M, O'Connor JM, Hannigan BM, Strain JJ. The immune system as a physiological indicator of marginal copper status? Br J Nutr. 2002;87:393-403.

65. Jones DG, Suttle NF. The effect of $\mathrm{Cu}$ deficiency on the resistance of mice to infection with Pasteurella haemolytica. J Comp Pathol. 1983;93:143-149.

66. Heresi G, Castillo-Duan C, Munoz C, Arevalo M, Schlesinger L. Phagocytosis and immunoglobulin levels in hypocupremic infants. Nutr Res. 1985;5:1327-1334.

67. Castillo-Duran C, Fisberg M, Valenzuela A, Egana JI, Uauy R. Controlled trial of copper supplementation during the recovery from marasmus. Am J Clin Nutr. 1983;37:898-893.

68. Prohaska JR, Lukasewycz OA. Effects of copper deficiency on the immune system. Adv Exp Med Biol. 1990;262:123-143.

69. Danks DM. Copper deficiency in humans. Ann Rev Nutr. 1988;8: 235-257. 
70. De Romania DL, Olivares M, Uauy R, Araya M. Risks and benefits of copper in light of new insights of copper homeostasis. J Trace Elem Med Biol. 2011;25:3-13.

71. Kelley DS, Daudu PA, Taylor PC, Mackey BE, Turnlund JR. Effects of low copper diets on human immune response. Am J Clin Nutr. 1995;62:412-416.

72. Huff JD, Keung YK, Thakuri M, et al. Copper deficiency causes reversible myelodysplasia. Am J Hematol. 2007;82:625-630.

73. Vanek VW, Borum P, Buchman A, et al. ASPEN position paper: recommendations for changes in commercially available parenteral multi-vitamin and multi-trace element products. Nutr Clin Pract. 2012;27:440-491.

74. Griffith DP, Liff D, Ziegler TR, Esper GJ, Winton EF. Acquired copper deficiency: a potentially serious and preventable complication following gastric bypass surgery. Obesity. 2009;17:827-831.

75. Bertinato J, Abbe MRL. Maintaining copper homeostasis: regulation of copper-trafficking proteins in response to $\mathrm{Cu}$ deficiency or overload. $J$ Nutr Biochem. 2004;15:316-322.

76. Agricultural Research Service. National Nutrient Database for Standard Reference. Washington, DC: US Department of Agriculture; 2016. Release 28.

77. Jayakumar S, Micallef-Eynaud PD, Lyon TDB, Cramb R, Jilaihawi AN, Prakash D. Acquired copper deficiency following prolonged jejunostomy feeds. Ann Clin Biochem. 2005;42:227-231.

78. Gaetke LM, Chow-Johnson HS, Chow CK. Copper: toxicological relevance and mechanisms. Arch Toxicol. 2014;88:1929-1938.

79. Merle U, Schaefer M, Ferenci P, Stremmel W. Clinical presentation, diagnosis and long term outcome of Wilson's disease: a cohort study. Gut. 2007;56:115-120.

80. Ferenci P, Steindl-Munda P, Vogel W, et al. Diagnostic value of quantitative hepatic copper determination in patients with Wilson's disease. Clin Gastroenterol Hepatol. 2005;3:811-818.

81. Blaszyk H, Wild PJ, Oliveira A, Kelly DG, Burgart LJ. Hepatic copper in patients receiving long term total parenteral nutrition. $J$ Clin Gastroenterol. 2005;39:318-320.

82. Howard L, Ashley C, Lyon D, Shenkin A. Autopsy tissue trace elements in eight long term parenteral nutrition patients who received the current US FDA formulation. JPEN J Parenter Enteral Nutr. 2007;31:388-396.

83. American Medical Association Department of Foods and Nutrition. Guidelines for essential trace element preparations for parenteral use. JAMA. 1979;241:2051-2054.

84. Danks DM. Copper and liver disease. Eur J Pediatr. 1991;150:142-148.

85. Linder MC. The relationship of copper to DNA damage and damage prevention in humans. Mutat Res. 2012;733:83-91.

86. Diaz G, Faa G, Farci AM, Balestrieri A, Liguori C, Costa V. Copper distribution within and between newborn livers. J Trace Elem Electrolytes Health Dis. 1990;4:61-64.

87. Schilsky ML, Blank RR, Czaja MJ, et al. Hepatocellular copper toxicity and its attenuation by zinc. J Clin Invest. 1989;84:1562-1568.

88. Brewer GJ. Iron and copper toxicity in diseases of aging, particularly atherosclerosis and Alzheimer's disease. Exp Biol Med. 2007;232:323-335.

89. Harvey LJ, Ashton K, Hopper L, Casgrain A, Fairweather-Tait SJ. Methods of assessment of copper status in humans: a systematic review. Am J Clin Nutr. 2009;89:2009S-2024S

90. González-Revaldería J, García-Bermejo S, Menchén-Herreros A, Fernández-Rodriguez E. Biological variation of $\mathrm{Zn}, \mathrm{Cu}$ and $\mathrm{Mg}$ in serum of healthy subjects. Clin Chem. 1990;36:2140-2141.

91. Fraser CG. Reference change values. Clin Chem Lab Med.2012;50:807-812.

92. Shike M, Roulet M, Kurian R, Whitwell J, Stewart S, Jeejeebhoy KN. Copper metabolism and requirements in total parenteral nutrition. Gastroenterol. 1981;81:290-297.

93. Steinlieb L, Scheinberg IH. Wilson disease. In: Bayliss TM, ed. Current Therapy in Gastroenterology and Liver Disease. 4th ed. Maryland Heights, MO: Mosby; 1994:578.

94. Roberts EA, Schilsky ML. AASLD practice guidelines. Diagnosis and treatment of Wilson disease: an update. Hepatology. 2008;47:2089-2111.
95. Taggart DP, Fraser WD, Shenkin A, Wheatley DJ, Fell GS. The effects of intra-operative hypothermia and cardiopulmonary bypass on trace elements and their protein binding ratios. Eur J Cardiothorac Surg. 1990;4:587-594.

96. Boullata JI. Trace elements in critically ill patients. J Infus Nurs. 2013;36:16-23.

97. Araya M, Olivares M, Pizarro F, Gonzalez M, Speisky H, Uauy R. Copper exposure and potential biomarkers of copper metabolism. Biometals. 2003;16:199-204.

98. Twomey PJ, Viljoen A, House IM, Reynolds TM, Wierzbicki AS. Adjusting copper concentrations for caeruloplasmin levels in routine clinical practice. J Clin Pathol. 2006;59:867-869.

99. Twomey PJ, Viljoen A, House IM, Reynolds TM, Wierzbicki AS. Copper: caeruloplasmin ratio. J Clin Pathol. 2007;60:441-442.

100. Twomey PJ, Wierzbicki AS, Reynolds TM, Viljoen A. The copper/caeruloplasmin ratio in routine clinical practice in different laboratories. $J$ Clin Pathol. 2009;62:60-63.

101. Pal A. Copper toxicity-induced hepatocerebral and neurodegenerative diseases: an urgent need for prognostic biomarkers. Neurotoxicology. 2014;40:97-101.

102. Olivares M, Mendez MA, Astudillo PA, Pizarro F. Present situation of biomarkers for copper status. Am J Clin Nutr. 2008;88:859S-862S.

103. Arredondo M, Weisstaub G, Medina M, Suazo M, Guzman M, Araya $\mathrm{M}$. Assessing chaperone for $\mathrm{Zn}, \mathrm{Cu}$-superoxide dismutase as an indicator of copper deficiency in malnourished children. J Trace Elem Med Biol. 2014;28:23-27.

104. Araya M, Gutierrez R, Arredondo M. CCS mRNA transcripts and serum CCS protein as copper marker in adults suffering inflammatory processes. Biometals. 2014;27:645-652.

105. Roberts EA, Schilsky ML; American Association for Study of Liver Diseases. Diagnosis and treatment of Wilson disease: an update. Hepatology. 2008;56:671-685.

106. Boaru SG, Merle U, Uerlings R, et al. Laser ablation inductively coupled plasma mass spectrometry imaging of metals in experimental and clinical Wilson's disease. J Cell Mol Med. 2015;19:806-814.

107. Allen LH. Micronutrient research, programs, and policy: from metaanalyses to metabolomics. Adv Nutr. 2014;5:344S-351S.

108. Cole RN, Ruczinski I, Schulze K, et al. The plasma proteome identifies expected and novel proteins correlated with micronutrients status in undernourished Nepalese children. J Nutr. 2013;143:1540-1548.

109. Santos EM, Ball JS, Williams TD, et al. Identifying health impacts of exposure to $\mathrm{Cu}$ using transcriptomics and metabolomics in a fish model. Environ Sci Technol. 2010;44:820-826.

110. Hines A, Staff FJ, Widdows J, Comptom RM, Falciani F, Viant MR. Discovery of metabolic signatures for predicting whole organism toxicology. Toxicol Sci. 2010;2010; 115:369-378.

111. Scheinberg IH, Sternlieb I. Wilson disease and idiopathic copper toxicosis. Am J Clin Nutr. 1996;63:8425-8555.

112. ASPEN Board of Directors and the Clinical Guidelines Task Force. Guidelines for the use of parenteral and enteral nutrition in adult and pediatric patients. JPEN $J$ Parenter Enteral Nutr. 2002;26:1SA-138SA.

113. Osland EJ, Ali A, Isenring E, Ball P, Davis M. Australasian Society for Parenteral and Enteral Nutrition guidelines for supplementation of trace elements during parenteral nutrition. Asia Pac J Clin Nutr. 2014;23:545-554.

114. Braga M, Ljunqvist O, Soeters P, Fearon K, Weimann A, Bozzetti F. ESPEN guidelines on parenteral nutrition: surgery. Clin Nutr. 2009;28:378-386.

115. Stehle P, Stoffel-Wagner B, Kuhn KS. Parenteral trace element provision: recent clinical research and practical conclusions [published online April 6, 2016]. Eur J Clin Nutr.

116. Abdalian R, Fernandes G, Duerksen D, et al. Prescription of trace elements in adults on home parenteral nutrition: current practice based on the Canadian Home Parenteral Nutrition Registry. JPEN J Parenter Enteral Nutr. 2013;37:410-415. 
117. Btaiche IF, Carver PL, Welch KB. Dosing and monitoring of trace elements in long term parenteral nutrition. JPEN J Parenter Enteral Nutr. 2011;35:736-747.

118. Shike M. Copper in parenteral nutrition. Gastroenterology. 2009;137:S13-S17.

119. Singer P, Berger MM, Van den Bergh G, et al. ESPEN guidelines on parenteral nutrition: intensive care. Clin Nutr. 2009;28:387-400.

120. Menendez AM, Weisstaub A, Montemerlo H, et al. Relationship between the amount of copper and zinc given to critically ill patients on total parenteral nutrition and plasma and erythrocyte copper and zinc levels. Nutr Hosp. 2008;23:373-382.

121. Ishizuka M, Nagata $H$, Takagi K, Kubota K. Sequential evaluations of trace elements in patients receiving parenteral nutrition. Hepatogastroenterology. 2011;58:1466-1469.

122. Staun M, Pironi L, Bozzetti F, et al. ESPEN guidelines on parenteral nutrition: home parenteral nutrition. Clin Nutr. 2009;28:467-479.

123. NICE. Nutrition Support in Adults: Oral Nutrition Support, Enteral Tube Feeding and Parenteral Nutrition. London, UK: NICE; 2006. NICE clinical guideline 32 .

124. Gagnon G, Voirol P, Soguel L, Boulat O, Berger MM. Trace element monitoring in the ICU: quality and economic impact of a change in sampling practice. Clin Nutr. 2015;34:422-427.

125. Fessler TA. Trace element monitoring and therapy for adult patients receiving long-term total parenteral nutrition. Pract Gastroenterol. 2005;25:44-65.

126. Pluhator-Murton MM, Fedorak RN, Audette RJ, Marriage BJ, Yatscoff RW, Gramlich LM. Trace element contamination of total parenteral nutrition: 1. Contribution of component solutions. JPEN J Parenter Enteral Nutr. 1999;23:222-227.

127. Menendez AM, Weisstaub AR, Montemerlo H, et al. Zinc and copper content in individual components used to prepare pediatric total nutrition mixtures. Nutr Hosp. 2007;22:545-551.
128. Berger MM, Cavadini C. Unrecognized intake of trace elements in polytraumatised and burnt patients. Ann Fr Anesth Reanmin. 1994;13:289-296.

129. Foinard A, Perez M, Barthelemy C, et al. In vitro assessment of interaction between amino acids and copper in neonatal parenteral nutrition. JPEN J Parenter Enteral Nutr. 2016;40:827-834.

130. Allwood MC, Martin H, Greenwood M, Maunder M. Precipitation of trace elements in parenteral nutrition mixtures. Clin Nutr. 1998;17:223-226.

131. Thibault M. Possible incompatability between amino acids and copper in solutions for pediatric parenteral nutrition. Can J Hosp Pharm. 2014;67:160-164.

132. Cochran EB, Boehm KA. Prefilter and postfilter cysteine/cystine and copper concentrations in pediatric parenteral nutrition solutions. JPEN J Parenter Enteral Nutr. 1992;16:460-463.

133. Boddapati S, Yang K, Muty R. Intravenous solution compatability and filter-retention characteristics of trace element preparations. Am J Hosp Pharm. 1981;38:1731-1736.

134. Burge JC, Flancbaum L, Holcombe B. Copper decreases ascorbic acid stability in total parenteral nutrition solutions. $J$ Am Diet Assoc. 1994;94(7):777-779.

135. Allwood MC, Kearney MC. Compatability and stability of additives in parenteral nutrition admixtures. Nutrition. 1998;14:697-706.

136. Allwood MC, Martin H, Greenwood M, Maunder M. Precipitation of trace elements in parenteral nutrition mixtures. Clin Nutr. 1998;17:223-226.

137. Vanek VW, Borum P, Buchman A, et al. A call to action to bring safer parenteral micronutrient products to the US market. Nutr Clin Pract. 2015;30:559-569.

138. Mirtallo JM, Holcombe B, Kochevar M, Guenter P. Parenteral nutrition product shortages: the ASPEN strategy. Nutr Clin Pract. 2012;27: 385-391.

139. Hassig TB, McKinzie BP, Fortier CR, Taber D. Clinical management strategies and implications for parenteral nutrition drug shortages in adult patients. Pharmacotherapy. 2014;34:72-84. 